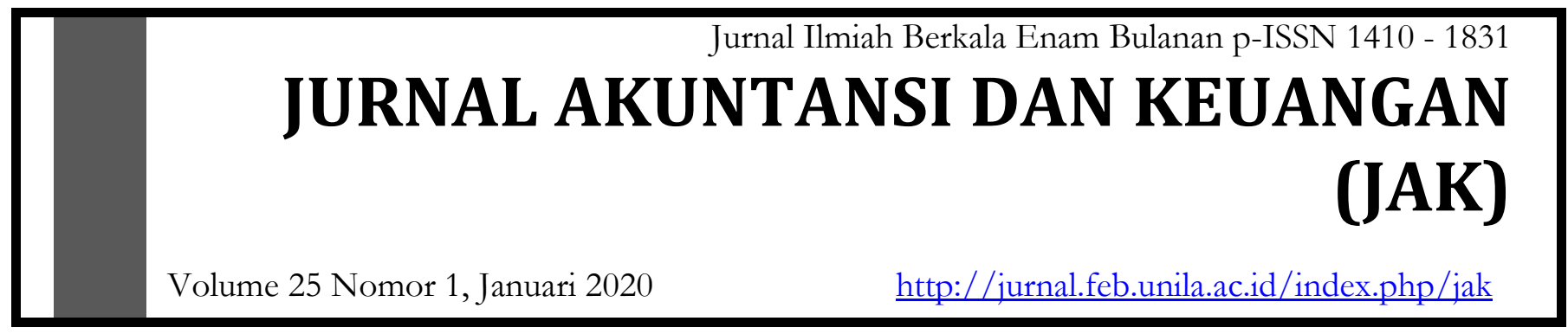

\title{
PENGARUH ELEMEN GOOD GOVERNANCE TERHADAP TINGKAT KORUPSI DI ASIA TENGGARA
}

\author{
Dinda Ayu Dizrisa ${ }^{1}$, Sudrajat. ${ }^{2}$, Niken Kusumawardani ${ }^{3}$ \\ ${ }^{1}$ Fakultas Ekonomi dan Bisnis, Universitas Lampung \\ ${ }^{2}$ Fakultas Ekonomi dan Bisnis, Universitas Lampung \\ 3 Fakultas Ekonomi dan Bisnis, Universitas Lampung
}

\section{Informasi Naskah}

Update Naskah:

Dikumpulkan: 9 Desembber 2019;

Diterima: 7 January 2020;

Terbit/Dicetak: 20 Januari 2020

\footnotetext{
Keywords:

Good governance, corruption levels, worldwide governance indicators, corruption perceptions index.
}

\section{$\underline{\text { Abstract }}$}

Corruption is a complex social, political and economic problem and occurs in every country with different levels. Corruption will complicate democracy and governance of a country. To overcome the problem of corruption, the government must implement good governance. This study aims to provide empirical evidence regarding the effect of elements of good governance on the level of corruption in Southeast Asia. Good governance variables are presented by six variables: voice and accountability, political stability and absence of violence / terrorism, government effectiveness, regulatory quality, rule of law and control of corruption.

Meanwhile, the level of corruption is measured using the Corruption Perceptions Index (CPI). The research sample was selected using the purposive sampling method and produced a sample of 8 countries and the observation period was carried out in 2009-2018 or as many as 10 years, so the number of samples in this study were 80 samples. Corruption level data used in this study uses the Corruption Perceptions Index (Transparency International), while the good governance data used in this study uses the Worldwide Governance Indicators (World Bank). The research methodology used in this study is multiple linear regression analysis with the IBM SPSS Statistics 24 program. The results showed that the variable voice and accountability, political stability and absence of violence / terrorism, and rule of law had no effect on the level of corruption, whereas the government variable effectiveness, regulatory quality, and control of corruption affect the level of corruption.

\footnotetext{
* Corresponding Author.

Niken Kusumawardani, e-mail : n1ken.kusumaward4ni@gmail.com
} 


\section{A. PENDAhULUAN}

Korupsi dapat terjadi di setiap negara dengan berbagai tingkatan yang berbeda dan dapat menyebabkan permasalahan sosial, politik dan ekonomi yang kompleks. Tidak ada konsensus internasional yang menjelaskan mengenai arti korupsi yang sesungguhnya. Dalam berbagai literatur, korupsi umumnya didefinisikan sebagai penyalahgunaan kekuasaan publik untuk mendapatkan keuntungan pribadi (Lambsdorff, 2007). Korupsi menggunakan jabatan publik sebagai kekuatan untuk mendapatkan keuntungan pribadi dengan cara yang bertentangan dengan rules of the game (Jain, 2001). Svensson (2005) melakukan penelitian untuk mengetahui ciri-ciri umum dari negara-negara yang dipersepsikan paling tinggi tingkat korupsinya di dunia. Dalam penelitian tersebut, Svensson melakukan peringkat terhadap $10 \%$ negara-negara dengan peringkat terbawah negara dengan tingkat korupsi tertinggi di dunia menurut Control of Corruption (World Bank), Corruption Perceptions Index (Transparency International), International Country Risk Guide (PRS Group), dan International Crime Victim Surveys (UNICRI). Berdasarkan penelitian tersebut, sebagian besar negara yang termasuk $10 \%$ peringkat terbawah negara dengan tingkat korupsi tertinggi di dunia merupakan negara berkembang.

Tabel $110 \%$ Negara Terkorup di Dunia

\begin{tabular}{|c|c|c|c|c|c|c|c|c|c|c|c|}
\hline No & Negara & $\mathrm{CoC}$ & No & Negara & CPI & No & Negara & ICRG & No & Negara & ICVS \\
\hline 1 & Guinea Ekuatorial & 1.9 & 1 & Bangladesh & 8.7 & 1 & Zimbabwe & 5.8 & 1 & Albania & 0.75 \\
\hline 2 & Haiti & 1.7 & 2 & Nigeria & 8.6 & 2 & China & 5 & 2 & Uganda & 0.36 \\
\hline 3 & Irak & 1.4 & 3 & Haiti & 8.5 & 3 & Gabon & 5 & 3 & Mozambik & 0.31 \\
\hline 4 & Kongo, Dem. Rep & 1.4 & 4 & Myanmar & 8.4 & 4 & Indonesia & 5 & 4 & Nigeria & 0.3 \\
\hline 5 & Myanmar & 1.4 & 5 & Paraguay & 8.4 & 5 & Irak & 5 & 5 & Lituania & 0.24 \\
\hline 6 & Afghanistan & 1.4 & 6 & Angola & 8.2 & 6 & Lebanon & 5 & & & \\
\hline 7 & Nigeria & 1.4 & 7 & Alzerbaijan & 8.2 & 7 & Myanmar & 5 & & & \\
\hline 8 & Laos & 1.3 & 8 & Kamerun & 8.2 & 8 & Niger & 5 & & & \\
\hline 9 & Paraguay & 1.2 & 9 & Georgia & 8.2 & 9 & Nigeria & 5 & & & \\
\hline 10 & Turkimenistan & 1.2 & 10 & Tajikistan & 8.2 & 10 & Rusia & 5 & & & \\
\hline 11 & Somalia & 1.2 & 11 & Indonesia & 8.2 & 11 & Sudan & 5 & & & \\
\hline 12 & Korea Utara & 1.2 & 12 & Kenya & 8.1 & 12 & Somalia & 5 & & & \\
\hline 13 & Zimbabwe & 1.2 & 13 & Cote d'Ivoire & 7.9 & 13 & Kongo, Dem. Rep & 5 & & & \\
\hline 14 & Indonesia & 1.2 & 14 & Kirghizia & 7.9 & 14 & Siberia dan & 5 & & & \\
\hline 15 & Angola & 1.1 & 15 & Libia & 7.9 & 15 & Montenegro & & & & \\
\hline 16 & Bangladesh & 1.1 & 16 & Papua Nugini & 7.9 & 16 & Haiti & 4.8 & & & \\
\hline 17 & Kamerun & 1.1 & & & & 17 & Papua Nugini & 4.8 & & & \\
\hline 18 & Niger & 1.1 & & & & & & & & & \\
\hline 19 & Sudan & 1.1 & & & & & & & & & \\
\hline 20 & Alzerbaijan & 1.1 & & & & & & & & & \\
\hline \multirow[t]{2}{*}{21} & Tajikistan & 1.1 & & & & & & & & & \\
\hline & Jumlah Sampel & 195 & & & 133 & & & 140 & & & \\
\hline
\end{tabular}

Sumber: Svensson, 2005.

Berdasarkan tabel di atas, peneliti menarik kesimpulan bahwa 10 (sepuluh) besar peringkat terbawah negara dengan tingkat korupsi tertinggi di dunia menurut 3 (tiga) dari 4 (empat) indeks yaitu $\mathrm{CoC}$, $C P I$, dan ICRG menunjukkan bahwa rata-rata 50\% negara dengan tingkat korupsi tertinggi di dunia berasal dari Benua Asia dan rata-rata 30\% negara di Benua Asia dengan peringkat terbawah negara dengan tingkat korupsi tertinggi tersebut berasal dari Asia Tenggara dan Asia Barat, kemudian disusul dengan Asia Selatan, Asia Tengah, dan Asia Timur. Hal ini merupakan angka yang cukup tinggi untuk permasalahan korupsi di Asia Tenggara. Berdasarkan indeks persepsi korupsi yang dikeluarkan oleh Transparency International, Singapura dari tahun ke tahun selalu menjadi urutan paling atas yang dipersepsikan lebih 
bebas dari korupsi dibandingkan dengan negara tetangga lainnya di Asia Tenggara, sedangkan Indonesia dan Myanmar pada tahun 2003 berada pada peringkat paling dasar bila dibandingkan dengan negara tetangganya di Asia Tenggara. Perbedaan indeks korupsi antara negara teratas yaitu Singapura dengan negara terbawah yaitu Indonesia dan Myanmar sangat besar (Wibowo, 2011). Hal ini menjadi menarik untuk dilihat apakah terdapat perbedaan karakteristik tata kelola pemerintahan pada negara-negara di Asia Tenggara.

Transparency International (2012) mencatat bahwa Singapura sebagai negara yang memiliki skor CPI tertinggi dengan skor 9,2 kemudian disusul dengan Brunei Darussalam 5,2. Malaysia 4,3. Thailand 3,4. Indonesia 3,0. Vietnam 2,9. Filipina 2,6. Laos 2,2. Kamboja 2,1. Myanmar 1,5. Dari data tersebut menunjukkan bahwa hanya Singapura dan Brunei Darussalam yang memiliki skor indeks korupsi diatas 5 . Dengan demikian dapat ditarik kesimpulan bahwa, 80 persen negara-negara di ASEAN memiliki permasalahan terhadap korupsi (Perdana dan Santosa, 2012). Korupsi akan menyebabkan sulitnya demokrasi dan tata pemerintahan suatu negara, serta akan mempersulit legitimasi pemerintahan. Transparansi merupakan tanda dari tingkat formalitas institusi. Transparansi dapat mengurangi praktik korupsi di suatu negara (Kolstad dan Wiig, 2008). Menurut penelitian yang dilakukan oleh Clark (2017), menjelaskan bahwa korupsi politik dapat merusak legitimasi pemerintah dan melemahkan perkembangan struktur politik, ekonomi, sosial, dan lingkungan. Sementara, pada penelitian yang dilakukan oleh Edo dkk. (2012) menyatakan bahwa umumnya kaum muda menilai buruk kinerja pemerintah karena adanya berbagai kasus korupsi yang terjadi di pemerintahan. Untuk mengatasi permasalahan korupsi di suatu negara, pemerintah wajib melaksanakan tata kelola pemerintahan yang baik (good governance).

Kemunculan good governance berawal dari tuntutan akan prasyarat yang dikenakan pada programprogram bantuan pembangunan berupa pinjaman dan bantuan keuangan. World Bank pertama kali mengeluarkan gagasan yang memperkenalkan good governance sebagai "program pengelolaan sektor publik" (public sector management program), dalam rangka penciptaan tata kelola pemerintahan yang baik dalam kerangka persyaratan bantuan dan pinjaman untuk pembangunan negara yang disebut dengan "selektivitas", yaitu komitmen dari negara penerima bantuan untuk menunjukkan keseriusannya terhadap reformasi pada bidang ekonomi, sosial dan termasuk beberapa aspek lainnya (Kharisma, 2014). Berdasarkan penelitian yang dilakukan oleh Javaid (2010) menyatakan bahwa tata kelola yang baik berkembang pada negara-negara yang bebas korupsi. Ketika suatu negara telah menerapkan tata kelola pemerintahan dengan baik maka negara tersebut akan bebas dari korupsi.

Prinsipnya, korupsi dan good governance adalah suatu hal yang kontras satu sama lain. Good governance mampu untuk mengurangi praktik korupsi melalui peningkatan kesadaran dan pengetahuan publik tentang korupsi dan penguatan aturan hukum yang tegas untuk melawan praktik korupsi. Sebaliknya bahwa praktik korupsi mampu menghalangi terwujudnya good governance serta akan menciptakan penyimpangan dalam pengambilan keputusan serta implementasi kebijakan (Edo dkk. 2012). Berdasarkan hal-hal yang telah dikemukakan diatas maka penelitian ini penting dilakukan untuk mengetahui pengaruh tata kelola pemerintahan yang baik untuk mengukur tingkat korupsi di suatu negara.

Pertanyaan yang ingin dijawab pada penelitian ini adalah apakah voice and accountability, political stability and absence of violencel terrorism, government effectiveness, regulatory quality, rule of law dan control of corruption berpengaruh terhadap tingkat korupsi di Asia Tenggara. Tujuan dari penelitian ini diharapkan dapat memperoleh bukti empiris mengenai pengaruh voice and accountability, political stability 
and absence of violence/ terrorism, government effectiveness, regulatory quality, rule of law dan control of corruption berpengaruh terhadap tingkat korupsi di Asia Tenggara. Selain itu, hasil penelitian ini diharapkan dapat memberikan informasi dan pengembangan ilmu pengetahuan mengenai elemen good governance yang berpengaruh terhadap tingkat korupsi di Asia Tenggara serta dapat memberikan masukan dalam penyusunan langkah-langkah pemberantasan korupsi khususnya bagi pemerintahan negara di Asia Tenggara dan dapat digunakan sebagai pertimbangan dalam membuat kebijakan untuk meningkatkan tata kelola yang baik pada pemerintahan negara di Asia Tenggara.

\section{B. LANDASAN TEORI DAN PENGEMBANGAN HIPOTESIS}

\section{Teori Keagenan}

Menurut Jensen dan Mecklin (1976) teori keagenan merupakan sebuah konsep yang menjelaskan hubungan kontraktual antara pihak prinsipal dan pihak agen, yaitu antara dua atau lebih individu, kelompok atau organisasi. Menurut Eisenhardt (1989) teori keagenan dilandasi oleh 3 (tiga) buah asumsi yaitu: (a) asumsi tentang sifat manusia yang menyatakan bahwa manusia memiliki sifat untuk mengutamakan diri sendiri, memiliki keterbatasan rasionalitas, dan tidak menyukai risiko, (b) asumsi tentang keorganisasian yang menyatakan mengenai adanya konflik antar anggota organisasi, efisiensi sebagai kriteria produktivitasnya, dan adanya asimetri informasi antara pihak prinsipal dan pihak agen, (c) Asumsi tentang informasi yang menyatakan bahwa informasi dipandang sebagai barang komoditi yang dapat diperjual belikan.

Berdasarkan asumsi diatas, sebagian besar manusia akan bertindak dengan mengutamakan kepentingan pribadinya. Pihak agen berkeinginan untuk meningkatkan pendapatan ekonomisnya, sedangkan pihak prinsipal berkeinginan untuk meningkatkan profitabilitasnya. Hal ini kemudian akan mendorong terjadinya konflik kepentingan antara pihak prinsipal dan pihak agen. Ketika pihak prinsipal mengawasi kegiatan yang dilakukan oleh pihak agen, maka pihak prinsipal akan memastikan bahwa pihak agen akan bertindak sebagaimana yang diinginkan pihak prinsipal.Dalam penelitian ini, teori keagenan digunakan sebagai dasar untuk menjelaskan konflik yang terjadi antara pemerintahan di Asia Tenggara yang berperan sebagai pihak agen dan masyarakat yang berperan sebagai pihak prinsipal terkait permasalahan korupsi di suatu negara. Pemerintah menerima perintah atas pengelolaan negara dan harus memberikan pelayanan kepada masyarakat. Termasuk juga pemerintah berkewajiban untuk memberantas korupsi guna mensejahterakan masyarakat dari tindakan yang dilakukan oleh orang-orang tertentu yang melanggar ketentuan hukum untuk mendapatkan keuntungan pribadi.

\section{Korupsi}

Korupsi merupakan fenomena yang sulit didefinisikan secara tepat dan komprehensif (Aidt, 2003). Secara terminologi, korupsi berasal dari bahasa Latin yaitu "corruptus" yang artinya kerusakan atau kebobrokan. Istilah korupsi kemudian muncul dalam beberapa bahasa seperti Perancis "corruption" dan Belanda "corruptie" yang selanjutnya menjadi "korupsi" dalam bahasa Indonesia (Jahja, 2012). Korupsi merupakan sesuatu yang busuk, jahat, dan merusak, berdasarkan fakta tersebut tindak korupsi terkait: sesuatu yang bersifat amoral, sifat dan keadaan yang busuk, menyangkut jabatan instansi atau aparatur pemerintah, penyelewengan kekuasaan dalam jabatan karena pemberian, menyangkut faktor ekonomi dan 
politik dan penempatan keluarga atau golongan kedalam kedinasan dibawah kekuasaan jabatan (Karsona, 2011). Menurut Undang-Undang Nomor 31 Tahun 1999 sebagaimana telah diubah dengan Undang-undang Nomor 20 Tahun 2001 tentang Pemberantasan Tindak Pidana Korupsi menyatakan bahwa korupsi adalah segala tindakan yang dapat merugikan keuangan negara dan menghambat pembangunan negara. Selain tidak hanya dapat merugikan keuangan negara, korupsi juga merupakan pelanggaran terhadap hak-hak sosial dan ekonomi masyarakat secara luas. Dari sekian banyak definisi yang ada, definisi yang sering digunakan sebagai acuan dalam studi korupsi lintas negara adalah definisi korupsi menurut Transparency International yaitu, korupsi merupakan penyalahgunaan wewenang yang digunakan untuk kepentingan pribadi (the abuse of entrusted power for private gain) (Pradiptyo, 2016).

Dapat ditarik kesimpulan bahwa, korupsi merupakan tindakan melanggar hukum dengan memanfaatkan jabatan publik untuk mendapatkan keuntungan pribadi atas penyalahgunaan jabatan publik tersebut dan dapat berpotensi merugikan keuangan negara. Transparency International setiap tahunnya menerbitkan indeks persepsi korupsi yang disebut dengan Corruption Perceptions Index (CPI). Transparency International merupakan sebuah organisasi internasional yang memelopori pemberantasan korupsi di dunia. Transparency International sejak mulai berdiri pada tahun 1993 telah mengeluarkan Corruption Perceptions Index (CPI) yang mengurutkan negara-negara di dunia berdasarkan anggapan (persepsi) publik terhadap korupsi politik (transparency.org). Corruption Perceptions Index (CPI) diukur dengan mengambil sampel survei persepsi publik atas dasar pandangan dari para pakar dan analis dari seluruh dunia (Tuanakotta, 2012). Corruption Perceptions Index (CPI) dapat menjelaskan tingkat korupsi disuatu negara dengan menggunakan skala 0-100. Jika suatu negara mendekati skor 0 maka dapat dikatakan bahwa negara tersebut merupakan negara dengan tingkat korupsi yang tinggi. Sebaliknya, jika suatu negara mendekati skor 100 maka dapat dikatakan bahwa negara tersebut merupakan negara yang bebas dari korupsi.

Indeks ini menunjukkan peringkat terhadap negara-negara sesuai dengan persepsi publik mengenai tingkat korupsi di suatu negara. Survei ini mencerminkan persepsi dan pandangan dari para pengusaha dan analis di seluruh dunia, termasuk para pakar dari negara yang disurvei. Korupsi yang digunakan dalam survei ini merupakan penyalahgunaan jabatan oleh para pegawai negeri dan kaum politisi untuk kepentingan pribadi, seperti penyuapan dalam proses pengadaan barang dan jasa publik. Survei ini tidak membedakan antara korupsi yang bersifat administratif atau politis, atau antara korupsi yang besar atau kecil (Tuanakotta, 2012). Berdasarkan survei yang telah dilakukan oleh Transparency International (1995), hasil survei mengenai Corruption Perceptions Index (CPI) dapat dipercaya dengan andal mengenai persepsi tingkat korupsi di suatu negara.

\section{Good Governance}

Tata kelola pemerintahan yang baik (good governance) merupakan isu mengenai pengelolaan administrasi publik (Rasul, 2009). Good governancemenurut World Bank (1992) merupakan suatu penyelenggaraan manajemen pembangunan yang solid dan bertanggungjawab yang sejalan dengan prinsip demokrasi dan pasar yang efisien, penghindaran kesalahan alokasi dana investasi, dan pencegahan korupsi baik secara politik maupun administratif, serta menjalankan disiplin anggaran serta penciptaan legal and political framework bagi pertumbuhan aktivitas usaha. Good governance dapat diartikan sebagai tata kelola pemerintahan yang baik dan bersih. Tata pemerintahan yang baik berkaitan dengan sumber sosial, budaya, 
politik serta ekonomi diatur sesuai dengan kekuasaan yang diamanatkan rakyat. Sedangkan, tata pemerintahan yang bersih merupakan pemerintahan yang efektif, efisien, transparan, jujur dan bertanggung jawab (Wiliyanti dkk. 2014).

Berdasarkan pemahaman mengenai good governance, Worldwide Governance Indicators, World Bank (1996) kemudian mengeluarkan karakteristik good governance yang disebut sebagai aggregate indicators of six broad dimensions of governance. Indikator ini digunakan sebagai alat ukur suatu negara untuk mengukur tata kelola pemerintahan yang baik. Ketika good governance suatu negara lemah, maka tingkat korupsi di suatu negara juga akan meningkat. Sebaliknya, ketika good governance suatu negara tersebut kuat, maka tingkat korupsi di suatu negara tersebut juga akan menurun.

Indikator pengukuran good governance berdasarkan Worldwide Governance Indicators antara lain sebagai berikut:

\section{a. Voice and Accountability}

Voice and accountability merupakan indikator yang menjelaskan sejauh mana warga negara dapat berpartisipasi dalam pemilihan pemerintahan negara, kebebasan berekspresi, kebebasan berserikat serta kebebasan pers (World Bank, 2007). Voice and accountability merupakan indeks tingkat penduduk negara yang berpartisipasi dalam proses politik, kebebasan berekspresi, kebebasan berkelompok, dan keterbukaan (Perdana dan Santosa, 2012).

\section{b. Political Stability and Absence of Violence/ Terrorism}

Political stability and absence of violence/ terrorism merupakan indikator yang menjelaskan adanya kemungkinan bahwa pemerintahan tidak berjalan dengan stabil atau dihentikan dengan cara yang tidak konstitusional, serta kemungkinan adanya bentuk tindak kekerasan dan terorisme di suatu negara (World Bank, 2007). Political stability and absence of violence/ terrorism juga merupakan indeks mengenai tingkat probabilitas bahwa pemerintah yang sah akan digulingkan secara inkonstitusional atau kekerasan, termasuk kekerasan berpolitik maupun terorisme (Perdana dan Santosa, 2012).

\section{c. Government Effectiveness}

Government effectiveness merupakan indikator yang menjelaskan kualitas layanan publik, kualitas layanan sipil, dan tingkat kemandirian dari tekanan politik, kualitas formulasi dan implementasi kebijakan, dan kredibilitas komitmen pemerintah terhadap kebijakan tersebut (World Bank, 2007). Government effectiveness juga merupakan indeks mengenai tingkat kualitas layanan publik, kualitas layanan masyarakat dan tingkat independensi dari tekanan politik, kualitas perumusan kebijakan dan pelaksanaan, kredibilitas komitmen pemerintah terhadap suatu kebijakan (Perdana dan Santosa, 2012).

\section{d. Regulatory Quality}

Regulatory quality merupakan indikator yang menjelaskan kemampuan pemerintah dalam merumuskan dan menerapkan kebijakan dan peraturan yang sehat yang mendorong pengembangan sektor swasta (World Bank, 2007). Regulatory quality merupakan indeks mengenai tingkat kemampuan pemerintah untuk merumuskan dan melaksanakan kebijakan serta peraturan yang memungkinkan untuk mempromosikan sektor swasta (Perdana dan Santosa, 2012). 


\section{e. Rule of Law}

Rule of lawmerupakan indikator yang menjelaskan kepercayaan pemerintah terhadap tegaknya aturan hukum masyarakat, dan kualitas penegakan kontrak, aparatur sipil, kepolisian, dan pengadilan, serta kemungkinan terjadinya tindak kejahatan dan kekerasan (World Bank, 2007). Rule of law merupakan indeks mengenai tingkat keyakinan dan kepatuhan agen penegak hukum dalam melaksanakan aturan, terkait dengan kualitas penegak kontrak, hak milik, polisi dan pengadilan, serta kemungkinan kejahatan dan kekerasan (Perdana dan Santosa, 2012).

\section{f. Control of Corruption}

Control of corruptionmerupakanindikator yang menjelaskan kekuasaan publik yang digunakan untuk meraup keuntungan pribadi, termasuk bentuk korupsi kecil maupun besar, serta pemberantasan korupsi yang dilakukan oleh pemerintah (World Bank, 2007). Control of corruption merupakan indeks mengenai tingkat persepsi mengenai kekuasaan publik dilaksanakan untuk kepentingan pribadi (Perdana dan Santosa, 2012).

\section{Pengaruh Voice and Accountability Terhadap Tingkat Korupsi}

Semakin baik tingkat partisipasi dalam proses demokrasi, berserikat dan kebebasan pers maka tingkat korupsi di suatu negara akan semakin rendah. Berdasarkan penelitian yang dilakukan oleh Perdana dan Santosa (2012) menyatakan bahwa variabel voice and accountability memiliki pengaruh yang signifikan terhadap corruption perceptions index (indeks perspektif korupsi). Penelitian yang dilakukan oleh Rasul (2009) menyatakan bahwa bila kesadaran akan akuntabilitas ini muncul dan menjadi kebutuhan bagi para penyelenggara negara maka akan meminimalisir tindak korupsi.

\section{$\mathrm{H}_{1}$ : Voice and accountability berpengaruh terhadap tingkat korupsi.}

\section{Pengaruh Political Stability and Absence of Violence/Terrorism Terhadap Tingkat Korupsi}

Semakin baik kestabilan politik maka tingkat korupsi di suatu negara akan semakin rendah. Berdasarkan penelitian yang dilakukan oleh Perdana dan Santosa (2012) menyatakan bahwa variabel political stability and absence of violencel terrorism memiliki pengaruh signifikan terhadap corruption perceptions index (indeks perspektif korupsi). Penelitian yang dilakukan oleh Edo dkk. (2012) menyatakan bahwa situasi stabil dan seimbang dalam dinamika berbangsa dan bernegara yang terwujud dapat menekan terjadinya diskriminasi yang menyebabkan kerusakan fisik atau barang orang lain dan meminimalisir praktik korupsi di suatu negara.

\section{$\mathrm{H}_{2}$ : Political stability and absence of violence/ terrorism berpengaruh terhadap tingkat korupsi}

\section{Pengaruh Government Effectiveness Terhadap Tingkat Korupsi}

Semakin tinggi tingkat efektivitas pemerintahan, kualitas layanan publik dan layanan sipil maka tingkat korupsi di suatu negara akan semakin rendah. Berdasarkan penelitian yang dilakukan oleh Edo dkk. (2012) menyatakan bahwa penyederhanaan prosedur administratif dan penguatan lembaga independen anti korupsi akan menjadi jalan keluar dalam rangka mewujudkan tata kelola pemerintahan yang baik (good governance). Penelitian selanjutnya yang dilakukan oleh Azra (2002) menyatakan bahwa dalam menangani 
penyebab-penyebab pokok korupsi diperlukan perumusan kebijakan-kebijakan yang dilakukan oleh pemerintah.

\section{$\mathrm{H}_{3}$ : Government effectiveness berpengaruh terhadap tingkat korupsi}

\section{Pengaruh Regulatory Quality Terhadap Tingkat Korupsi}

Semakin baik kualitas regulasi dan kebijakan maka tingkat korupsi di suatu negara akan semakin rendah. Berdasarkan penelitian yang dilakukan oleh Azra (2002) menjelaskan bahwa perubahan kebijakan yang lebih baik akan mendorong seseorang untuk mengurangi praktik korupsi. Penelitian yang dilakukan oleh Rasul (2009) menyatakan bahwa pembuatan kebijakan diperlukan untuk mengukur biaya pembuatan kebijakan dengan kemungkinan adanya peluang untuk melakukan tindak korupsi.

\section{$\mathrm{H}_{4}$ : Regulatory quality berpengaruh terhadap tingkat korupsi}

\section{Pengaruh Rule of Law Terhadap Tingkat Korupsi}

Semakin baik aturan hukum negara maka tingkat korupsi akan semakin rendah. Berdasarkan penelitian yang dilakukan oleh Azra (2002) menyatakan bahwa mereformasi lembaga-lembaga hukum untuk menciptakan, menegakkan hukum (law enforcement) dan memperkuat rule of law guna memberantas korupsi. Penelitian yang dilakukan oleh Rasul (2009) menyatakan bahwa aparat penegak hukum yang berkualitas dan berintegritas dapat melakukan pemberantasan tindak korupsi secara efektif dan optimal.

\section{H5: Rule of law berpengaruh terhadap tingkat korupsi}

\section{Pengaruh Control of Corruption Terhadap Tingkat Korupsi}

Semakin baik pencegahan korupsi maka tingkat korupsi di suatu negara akan semakin rendah. Berdasarkan penelitian yang dilakukan oleh Perdana dan Santosa (2012) menyatakan bahwa variabel control of corruption memiliki pengaruh signifikan terhadap corruption perceptions index (indeks perspektif korupsi). Namun, hasil penelitian yang dilakukan oleh Dana dkk. (2017) menyatakan bahwa control of corruption tidak dapat memberikan pengaruh terhadap korupsi.

\section{H6: Control of corruption berpengaruh terhadap tingkat korupsi}

\section{Gambar 2.1}

Kerangka Pemikiran

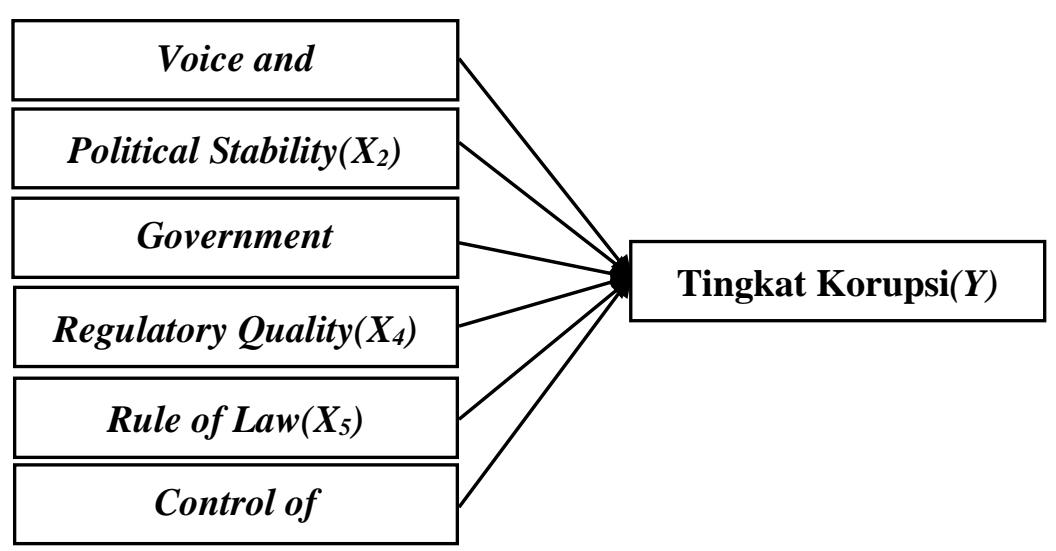




\section{METODE PENELITIAN}

\section{Populasi dan Sampel}

Populasi dalam penelitian ini adalah negara-negara di Asia Tenggara. Pengambilan sampel dilakukan dengan metode purposive sampling.

Adapun kriteria yang menjadi pertimbangan dalam pengambilan sampel adalah sebagai berikut:

1. Negara yang berada di wilayah Asia Tenggara.

2. Negara yang memiliki indeks persepsi korupsi yang dikeluarkan oleh Transparency International dari tahun 2009-2018.

3. Negara yang memiliki indikator good governance yang dikeluarkan oleh Worldwide Governance Indicators, World Bank dari tahun 2009-2018.

Adapun jenis dan sumber data yang digunakan dalam penelitian ini adalah data sekunder. Data sekunder diperoleh dari data-data internasional yang didapatkan melalui Transparency International dan World Bank dari tahun 2009-2018.

\section{Tingkat Korupsi}

Tingkat korupsi diukur dengan menggunakan indeks korupsi di setiap negara di Asia Tenggara. Indeks yang digunakan dalam penelitian ini adalah Corruption Perceptions Index (CPI) yang dikeluarkan oleh Transparency International. Selanjutnya variabel ini akan disimbolkan dengan $(Y)$ dalam persamaan.

\section{Voice and Accountability}

Memuat persepsi mengenai kemampuan warga negara untuk turut serta berpartsipasi dalam proses demokrasi, termasuk kebebasan berekspresi dan berserikat, dan kebebasan pers. Variabel ini mencakup beberapa komponen, seperti yang dijelaskan dalam Kaufmann et al. (2010). Variabel ini diukur dalam satuan distribusi normal standar, mulai dari -2.5 hingga 2.5 dengan satuan yang lebih tinggi menunjukkan kepercayaan yang lebih besar pada akuntabilitas negara (Spiteri dan Briguglio, 2018). Variabel ini akan disimbolkan dengan $\left(X_{l}\right)$ dalam persamaan.

\section{Political Stability and Absence of Violence/ Terrorism}

Memuat persepsi mengenai kemungkinan terjadinya ketidakstabilan politik, kekerasan bermotivasi politik, dan terorisme di setiap negara. Variabel ini mencakup beberapa komponen, seperti yang dijelaskan dalam Kaufmann et al. (2010). Variabel ini diukur dalam satuan distribusi normal standar, mulai dari -2.5 hingga 2.5 dengan satuan yang lebih tinggi menunjukkan tingkat stabilitas politik yang lebih tinggi dan berkurangnya kekerasan di suatu negara (Spiteri dan Briguglio, 2018). Variabel ini akan disimbolkan dengan $\left(X_{2}\right)$ dalam persamaan.

\section{Government Effectiveness}

Memuat persepsi mengenai kualitas layanan publik, perumusan dan implementasi kebijakan, dan layanan sipil. Variabel ini mencakup beberapa komponen, seperti yang dijelaskan dalam Kaufmann et al. (2010). Variabel ini diukur dalam satuan distribusi normal standar, mulai dari -2.5 hingga 2.5 dengan satuan yang lebih tinggi menunjukkan tingkat efektivitas pemerintah yang lebih tinggi (Spiteri dan Briguglio, 2018). Variabel ini akan disimbolkan dengan $\left(X_{3}\right)$ dalam persamaan. 


\section{Regulatory Quality}

Memuat persepsi mengenai kualitas kebijakan dan peraturan pemerintah untuk mempromosikan perusahaan sektor swasta. Variabel ini mencakup beberapa komponen, seperti yang dijelaskan dalam Kaufmann et al. (2010). Variabel ini diukur dalam satuan distribusi normal standar, mulai dari -2.5 hingga 2.5 dengan satuan yang lebih tinggi menunjukkan tingkat kualitas regulasi yang lebih tinggi (Spiteri dan Briguglio, 2018). Variabel ini akan disimbolkan dengan $\left(X_{4}\right)$ dalam persamaan.

\section{Rule of Law}

Memuat persepsi mengenai kepercayaan umum terhadap aturan hukum negara, termasuk peradilan, kepolisian, penegakan kontrak dan perlindungan hak milik, serta sejauh mana aturan hukum ditaati warga negara. Variabel ini mencakup beberapa komponen, seperti yang dijelaskan dalam Kaufmann et al. (2010). Variabel ini diukur dalam satuan distribusi normal standar, mulai dari -2.5 hingga 2.5 dengan satuan yang lebih tinggi menunjukkan tingkat kepercayaan yang lebih besar pada aturan hukum negara (Spiteri dan Briguglio, 2018). Variabel ini akan disimbolkan dengan $\left(X_{5}\right)$ dalam persamaan.

\section{Control of Corruption}

Memuat persepsi mengenai sejauh mana pemerintah nasional di setiap negara dianggap untuk mencegah atau mengurangi timbulnya semua bentuk tindak korupsi di suatu negara. Variabel ini mencakup beberapa komponen, seperti yang dijelaskan dalam Kaufmann et al. (2010). Variabel ini diukur dalam satuan distribusi normal standar, mulai dari -2.5 hingga 2.5 dengan satuan yang lebih tinggi menunjukkan tingkat kontrol korupsi yang lebih baik (Spiteri dan Briguglio, 2018). Variabel ini akan disimbolkan dengan $\left(X_{6}\right)$ dalam persamaan.

\section{ANALISIS DAN PEMBAHASAN}

\section{Koefisien Determinan (Adjusted $\mathbf{R}^{2}$ )}

\section{Model Summary ${ }^{b}$}

\begin{tabular}{|c|c|c|c|c|}
\hline Model & $\mathrm{R}$ & R Square & Adjusted R Square & Std. Error of the Estimate \\
\hline 1 &, $780^{\mathrm{a}}$ & 608 &, 576 & ,28000 \\
\hline
\end{tabular}

a. Predictors: (Constant), LN_X6, LN_X1, LN_X3, LN_X4, LN_X5, LN_X2

b. Dependent Variable: LN_Y

Berdasarkan tabel diatas hasil uji koefisien determinan (adjusted $R^{2}$ ) diperoleh nilai Adjusted $R^{2}$ sebesar 0,576 yang berarti bahwa variabel independen yaitu voice and accountability $\left(\mathrm{X}_{1}\right)$, political stability and absence of violencel terrorism $\left(\mathrm{X}_{2}\right)$, government effectiveness $\left(\mathrm{X}_{3}\right)$, regulatory quality $\left(\mathrm{X}_{4}\right)$, rule of law $\left(\mathrm{X}_{5}\right)$ dan control of corruption $\left(\mathrm{X}_{6}\right)$ mampu menjelaskan variabel dependen yaitu tingkat korupsi sebesar 57,6\% dan 42,4\% dijelaskan oleh variabel lain yang tidak termasuk dalam model penelitian ini.

\section{Uji Statistik t}

\begin{tabular}{|c|c|c|c|c|c|}
\hline \multicolumn{6}{|c|}{ Coefficients $^{\mathrm{a}}$} \\
\hline \multirow[t]{2}{*}{ Model } & \multicolumn{2}{|c|}{ Unstandardized Coefficients } & $\begin{array}{c}\text { Standardized } \\
\text { Coefficients }\end{array}$ & $\mathbf{t}$ & Sig. \\
\hline & B & Std. Error & Beta & & \\
\hline
\end{tabular}




\begin{tabular}{l|l|l|l|c|c}
\hline (Constant) & 4,006 &, 066 & & 60,908 &, 000 \\
\hline LN_X1 &, 059 &, 034 &, 137 & 1,748 &, 085 \\
\hline LN_X2 &, 041 &, 053 &, 074 &, 769 &, 444 \\
\hline LN_X3 &, 064 &, 026 &, 210 & 2,486 &, 015 \\
\hline LN_X4 &, 178 &, 042 &, 366 & 4,181 &, 000 \\
\hline LN_X5 &, 100 &, 051 &, 181 & 1,936 &, 057 \\
\hline LN_X6 &, 113 &, 054 &, 209 & 2,110 &, 038 \\
\hline
\end{tabular}

a. Dependent Variable: LN_Y

Berdasarkan tabel diatas dapat dijelaskan bahwa:

1. Variabel $X_{1}$ memiliki nilai signifikansi sebesar 0,085 nilai tersebut $>0,05$, maka dapat disimpulkan bahwa voice and accountability $\left(\mathrm{X}_{1}\right)$ tidak berpengaruh terhadap tingkat korupsi atau $\mathrm{H}_{1}$ tidak terdukung.

2. Variabel $X_{2}$ memiliki nilai signifikansi sebesar 0,444 nilai tersebut $>0,05$, maka dapat disimpulkan bahwa political stability and absence of violence/ terrorism $\left(\mathrm{X}_{2}\right)$ tidak berpengaruh terhadap tingkat korupsi atau $\mathrm{H}_{2}$ tidak terdukung.

3. Variabel $\mathrm{X}_{3}$ memiliki nilai signifikansi sebesar 0,015 nilai tersebut $<0,05$, maka dapat disimpulkan bahwa government effectiveness $\left(\mathrm{X}_{3}\right)$ berpengaruh terhadap tingkat korupsi atau $\mathrm{H}_{3}$ terdukung.

4. Variabel $\mathrm{X}_{4}$ memiliki nilai signifikansi sebesar 0,000 nilai tersebut $<0,05$, maka dapat disimpulkan bahwa regulatory quality $\left(\mathrm{X}_{4}\right)$ berpengaruh terhadap tingkat korupsi atau $\mathrm{H}_{4}$ terdukung.

5. Variabel $\mathrm{X}_{5}$ memiliki nilai signifikansi sebesar 0,057 nilai tersebut $>0,05$, maka dapat disimpulkan bahwa rule of law $\left(\mathrm{X}_{5}\right)$ tidak berpengaruh terhadap tingkat korupsi atau $\mathrm{H}_{5}$ tidak terdukung.

6. Variabel $\mathrm{X}_{6}$ memiliki nilai signifikansi sebesar 0,038 nilai tersebut $<0,05$, maka dapat disimpulkan bahwa control of corruption $\left(\mathrm{X}_{6}\right)$ berpengaruh terhadap tingkat korupsi atau $\mathrm{H}_{6}$ terdukung.

\section{PEMBAHASAN}

\section{Pengaruh Voice and Accountability Terhadap Tingkat Korupsi}

Hipotesis pertama menunjukkan bahwa voice and accountability tidak berpengaruh terhadap tingkat korupsi. Hasil pengujian hipotesis pada lampiran 13 nilai voice and accountability $\left(\mathrm{X}_{1}\right)$ menunjukkan arah positif dengan nilai koefisien beta sebesar 0,059 dan nilai signifikansi sebesar 0,085>0,05 sehingga dapat disimpulkan bahwa voice and accountabilty tidak memiliki pengaruh terhadap tingkat korupsi atau $\mathrm{H}_{1}$ tidak terdukung.

Hal yang menyebabkan voice and accountability tidak berpengaruh terhadap tingkat korupsi adalah jumlah pemilih tidak berpengaruh dengan tingkat korupsi meskipun tingkat partisipasi pemilu tinggi baik untuk pemilihan lokal maupun nasional (Lewis, 2006). Namun, survei yang dilakukan di Filipina menujukkan bahwa tingkat korupsi yang rendah berhubungan dengan pemungutan suara dalam pemilihan lokal dan warga tetap aktif dalam pemerintahan meskipun terjadi korupsi (Lewis, 2006). Hasil penelitian Lindstedt dan Naurin (2005) dalam Lambsdorff (2007) menyatakan bahwa kebebasan pers akan mengurangi korupsi, tetapi terbatas pada demokrasi dan tingkat pendidikan yang lebih tinggi, dapat disimpulkan bahwa penerapan pendidikan anti korupsi pada kebebasan pers, tidak cukup untuk memengaruhi tingkat korupsi. 
Sistem otoritarisasi yang dilakukan oleh rezim Junta Militer di Myanmar mengalami permasalahan yang kompleks, salah satunya yaitu tidak adanya kebebasan pers di Myanmar ditunjukkan dengan adanya larangan penulisan terhadap isu-isu tertentu seperti masalah Hak Asasi Manusia dan tahanan politik (Apriyanti, 2014). Sebelum terjadinya reformasi politik dan ekonomi pada pemerintahan U Thein Sein di Myanmar tahun 2012, World Press Freedom Indexyang dikeluarkan oleh Reporters Without Borders (2011)menyatakan Myanmar menduduki peringkat ke 169 dari 179 negara yang di survei dengan skor sebesar 100. Hal ini menunjukkan bahwa Myanmar memiliki tingkat kebebasan pers yang sangat rendah, ditandai skor $100>70$ yang masuk dalam kategori paling tidak bebas (least free). Menurut Apriyanti (2014), pers cenderung dimanipulasi dan digunakan untuk kepentingan dan pencitraan diri oleh rezim Junta Militer. Rendahnya kebebasan pers yang dialami Myanmar pada tahun 2011 tidak mempengaruhi hasil skor indeks perspektif korupsi Myanmar pada tahun tersebut, dapat dilihat pada lampiran 1 menunjukkan bahwa hasil skor corruption perceptions index (CPI) mengalami peningkatan dari tahun sebelumnya.

Berdasarkan pada lampiran 1, dapat dilihat bahwa kenaikan skor voice and accountability tidak sejalan dengan kenaikan skor corruption perceptions index (CPI). Terdapat beberapa negara yang mengalami peningkatan skor voice and accountability tetapi skor corruption perceptions index (CPI) mengalami penurunan, atau sebaliknya. Terjadinya penurunan hasil skor voice and accountability tetapi skor corruption perceptions index (CPI) mengalami peningkatan terjadi pada beberapa negara antara lain: Thailand (2010), Filipina dan Timor Leste (2012), Malaysia dan Thailand (2014), Singapura (2015), Indonesia dan Vietnam (2016), Filipina, Myanmar, Thailand dan Vietnam (2017), dan Filipina (2018). Sebaliknya, terjadinya peningkatan hasil skor voice and accountability tetapi skor corruption perceptions index (CPI) mengalami penurunan terjadi pada beberapa negara antara lain: Malaysia, Singapura, Thailand dan Timor Leste (2011), Singapura (2012), Timor Leste (2014), Singapura (2016), Malaysia (2017), serta Thailand dan Timor Leste (2018). Berdasarkan hal tersebut, maka dapat disimpulkan bahwa tinggi rendahnya tingkat skor voice and accountability tidak memengaruhi peningkatan atau penurunan corruption perceptions index (CPI) di suatu negara.

\section{Pengaruh Political Stability and Absence of Violence/ Terrorism Terhadap Tingkat Korupsi}

Hipotesis kedua menunjukkan bahwa political stability and absence of violencel terrorism tidak berpengaruh terhadap tingkat korupsi. Hasil pengujian hipotesis pada lampiran 13 nilai political stability and absence of violence/ terrorism $\left(\mathrm{X}_{2}\right)$ menunjukkan arah positif dengan nilai koefisien beta sebesar 0,041 dan nilai signifikansi sebesar 0,444 > 0,05 sehingga dapat disimpulkan bahwa political stability and absence of violence/ terrorism tidak memiliki pengaruh terhadap tingkat korupsi atau $\mathrm{H}_{2}$ tidak terdukung.

Hal yang menyebabkan political stability and absence of violence/ terrorism tidak berpengaruh terhadap tingkat korupsi adalah ketidakmampuan politik dapat menyebabkan protes publik, tantangan bagi rezim yang berkuasa bahkan invasi eksternal (Treisman, 2000). Lebih lanjut, Lambsdorff (2007) menjelaskan bahwa jika aspek ketidakstabilan politik ditambahkan dalam perhitungan pengukuran tingkat korupsi maka hal tersebut tidak dapat dilakukan.

Ketidakstabilan politik berupa kudeta militer terjadi di Thailand pada 7 Mei 2014 ketika militer Thailand meluncurkan kudeta terhadap pemerintahan Perdana Menteri Yingluck Shinawatra yang mengakhiri jabatannya sebagai perdana menteri sejak terpilih pada 5 Agustus 2011 (Prakoso, 2014). 
Campur tangan kekuatan militer di politik Thailand, berawal dari peran militer sebagai Dewan Penasihat yang mengamati kesalahan dalam pemerintahan sipil yang dilakukan oleh pemerintahan Perdana Menteri Yingluck Shinawatra. Kudeta terjadi akibat kekuatan militer selalu dapat campur tangan dalam urusan politik di Thailand dan menyebabkan pergantian kekuasaan (Prakoso, 2014). Ketidakstabilan politik yang dialami Thailand pada tahun 2014 ini tidak mempengaruhi hasil skor indeks perspektif korupsi Thailand pada tahun tersebut, dapat dilihat pada lampiran 1 menunjukkan bahwa hasil skor corruption perceptions index (CPI) mengalami peningkatan dari tahun sebelumnya.

Berdasarkan pada lampiran 1, dapat dilihat bahwa kenaikan skor political stability and absence of violencel terrorism tidak sejalan dengan kenaikan skor corruption perceptions index (CPI). Terdapat beberapa negara yang mengalami peningkatan skor political stability and absence of violence/ terrorism tetapi skor corruption perceptions index (CPI) mengalami penurunan, atau sebaliknya. Terjadinya penurunan hasil skor political stability and absence of violencel terrorism tetapi skor corruption perceptions index (CPI) mengalami peningkatan terjadi pada beberapa negara antara lain: Singapura dan Thailand (2010), Malaysia dan Thailand (2012), Myanmar (2013), Indonesia dan Myanmar (2015), Myanmar (2017), serta Indonesia dan Singapura (2018). Sebaliknya, terjadinya peningkatan hasil skor political stability and absence of violencel terrorism tetapi skor corruption perceptions index (CPI) mengalami penurunan terjadi pada beberapa negara antara lain: Malaysia (2010), Singapura, Thailand dan Timor Leste (2011), Singapura (2012), Singapura (2013), Timor Leste (2014), Singapura (2016), Malaysia dan Filipina (2017), serta Thailand dan Timor Leste (2018). Berdasarkan hal tersebut, maka dapat disimpulkan bahwa tinggi rendahnya tingkat skor political stability and absence of violence/ terrorism tidak memengaruhi peningkatan atau penurunan corruption perceptions index (CPI) di suatu negara.

\section{Pengaruh Government Effectiveness Terhadap Tingkat Korupsi}

Hipotesis ketiga menunjukkan bahwa government effectiveness berpengaruh terhadap tingkat korupsi. Hasil pengujian hipotesis pada lampiran 13 nilai government effectiveness $\left(\mathrm{X}_{3}\right)$ menunjukkan arah positif dengan nilai koefisien beta sebesar 0,064 dan nilai signifikansi sebesar 0,015 $<0,05$ sehingga dapat disimpulkan bahwa government effectiveness memiliki pengaruh terhadap tingkat korupsi atau $\mathrm{H}_{3}$ terdukung.

Hasil penelitian ini mendukung survei yang dilakukan oleh Transparency International (2010) dalam Global Corruption Barometer yang menjelaskan temuan-temuan pada negara dimana survei dilakukan terkait dengan lembaga yang paling dipercaya dalam upaya pemberantasan korupsi dengan pandangan government effectiveness. Hasil survei menunjukkan bahwa government leaders merupakan lembaga dengan skor tertinggi paling efektif dalam upaya pemberantasan korupsi berdasarkan efektivitas pemerintah dengan skor $49 \%$ dan government leaders merupakan lembaga dengan skor terendah kedua paling tidak efektif dalam upaya pemberantasan korupsi berdasarkan efektivitas pemerintah dengan skor $11 \%$ (lihat lampiran 14). Hal ini menujukkan bahwa kualitas lembaga pelayanan publik yaitu government leaders mampu melakukan pemberantasan korupsi di suatu negara.

Hasil penelitian ini juga menguatkan penelitian yang dilakukan oleh Fatkhuri (2017) yang menyatakan bahwa berdasarkan hasil survei BPS tahun 2015 mengenai Indeks Perilaku Anti Korupsi menujukkan bahwa masyarakat rata-rata memiliki pengalaman terlibat dalam tindakan korupsi ketika berurusan dengan masalah pelayanan publik. Hasil penelitian ini juga sejalan dengan penelitian yang 
dilakukan oleh Rasul (2009) yang menyatakan bahwa permasalahan yang timbul karena adanya korupsi antara lain rendahnya kualitas pelayanan publik, rendahnya kualitas sarana dan prasarana publik, dan meningkatnya beban masyarakat akibat ketidakefektifan dan efisienan dalam pengelolaan badan usaha yang mengelola kebutuhan publik.

\section{Pengaruh Regulatory Quality Terhadap Tingkat Korupsi}

Hipotesis keempat menunjukkan bahwa regulatory quality berpengaruh terhadap tingkat korupsi. Hasil pengujian hipotesis pada lampiran 13 nilai regulatory quality $\left(\mathrm{X}_{4}\right)$ menunjukkan arah positif dengan nilai koefisien beta sebesar 0,178 dan nilai signifikansi sebesar 0,000 $<0,05$ sehingga dapat disimpulkan bahwa regulatory quality memiliki pengaruh terhadap tingkat korupsi atau $\mathrm{H}_{4}$ terdukung.

Hasil penelitian ini mendukung penelitian yang dilakukan oleh Perdana dan Santosa (2012) yang menyatakan bahwa regulatory quality memiliki pengaruh yang signifikan terhadap corruption perceptions index (indeks perspektif korupsi). Gerring dan Thacker (2005) menyatakan bahwa terdapat hubungan yang positif antara regulatory quality dan tidak adanya korupsi di suatu negara. Svensson (2005), menyatakan bahwa terdapat hubungan yang kuat antara korupsi dengan regulasi pasar yaitu kewenangan yang dimiliki oleh birokrat dalam merumuskan dan menerapkan kebijakan dapat memengaruhi tingkat korupsi. Para pejabat seringkali mengeluarkan aturan-aturan yang menghambat masuknya pesaing supaya dapat melakukan korupsi (De Soto, 1989; Shleifer dan Vishny, 1993). Jadi, deregulasi dapat mengurangi korupsi bukan karena deregulasi tersebut dapat meningkatkan persaingan, melainkan karena deregulasi dapat mengurangi kewenangan birokrat.

Hasil penelitian ini mendukung penelitian yang dilakukan oleh Pradiptyo (2016) yang menyatakan bahwa state captures corruption merupakan korupsi yang disebabkan oleh penyalahgunaan kewenangan pemerintah dalam membuat kebijakan dan undang-undang yang memberikan keuntungan bagi sektor swasta yaitu korporasi dan kebijakan tersebut inefisien bagi masyarakat. Hasil penelitian ini juga sejalan dengan penelitian yang dilakukan oleh Umar (2011) yang menjelaskan bahwa korupsi akan mengurangi kemampuan pemerintah dalam melakukan pembenahan peraturan akibat terjadinya kegagalan pasar (market failure). Ketika kebijakan dipengaruhi oleh korupsi, maka pengenaan peraturan dan kebijakan tersebut akan menimbulkan inefisiensi kebijakan.

\section{Pengaruh Rule of Law Terhadap Tingkat Korupsi}

Hipotesis kelima menunjukkan bahwa rule of law tidak berpengaruh terhadap tingkat korupsi. Hasil pengujian hipotesis pada lampiran 13 nilai rule of law $\left(\mathrm{X}_{5}\right)$ menunjukkan arah positif dengan nilai koefisien beta sebesar 0,100 dan nilai signifikansi sebesar 0,057 > 0,05 sehingga dapat disimpulkan bahwa rule of law tidak memiliki pengaruh terhadap tingkat korupsi atau $\mathrm{H}_{5}$ tidak terdukung.

Hal yang menyebabkan rule of law tidak berpengaruh terhadap tingkat korupsi adalah aturan hukum terkait lamanya pidana yang dijalankan oleh pelaku tindak pidana korupsi tidak memiliki pengaruh terhadap penghukuman kembali atas perilaku korupsi tersebut. Dalam penanganan permasalahan korupsi tidak hanya mengandalkan hukum (pidana) saja, namun berbagai upaya lain tetap harus ditingkatkan baik untuk pencegahan korupsi atau penghukuman bagi pelaku tindak pidana korupsi (Elwina, 2011). Selain itu, menurut Kurniadi (2011) penegakan hukum di suatu negara selain bergantung pada aparatur hukum maupun sarana dan prasarana hukum, juga bergantung pada kesadaran hukum masyarakat. Angka kejahatan 
akan berkurang jika timbul kesadaran hukum masyarakat. Aturan hukum yang berlaku tidak akan berpengaruh terhadap tindak kejahatan apabila masih rendahnya kesadaran hukum masyarakat. Penanganan terhadap permasalahan korupsi akan terwujud jika tingkat kesadaran hukum dan kesejahteraan masyakat sudah memadai.

Tren Vonis Kasus Korupsi 2018 yang dikeluarkan oleh Indonesia Corruption Watch (2018) menyimpulkan bahwa terdapat enam permasalahan terkait tren vonis perkara korupsi diantaranya: (1) ratarata putusan pada seluruh tingkat pengadilan dapat dikatakan ringan, yaitu 2 tahun 5 bulan; (2) permasalahan pengembalian aset yang belum maksimal ditandai dengan $8.7 \%$ kerugian negara yang diganti melalui pidana tambahan uang pengganti; (3) rendahnya sanksi bagi pelaku pungli; (4) tingginya disparitas putusan pengadilan; (5) rendahnya pencabutan hak politik bagi para terdakwa yang memiliki latar belakang karir politik; (6) tingginya pengajuan PK oleh banyaknya terpidana korupsi terutama yang perkaranya ditangani oleh KPK. Banyaknya masalah terkait tren vonis perkara korupsi yang di hadapi Indonesia pada tahun 2018 mengakibatkan tidak adanya efek jera bagi para pelaku tindak pidana korupsi ini dan hal ini tidak mempengaruhi hasil skor indeks perspektif korupsi Indonesia pada tahun tersebut, dapat dilihat pada lampiran 1 menunjukkan bahwa hasil skor corruption perceptions index (CPI) mengalami peningkatan dari tahun sebelumnya.

Hasil penelitian ini mendukung penelitian yang dilakukan oleh Perdana dan Santosa (2012) yang menjelaskan bahwa rule of law tidak memiliki pengaruh yang signifikan terhadap corruption perceptions index (indeks perspektif korupsi). Berdasarkan pada lampiran 1, dapat dilihat bahwa kenaikan skor rule of law tidak sejalan dengan kenaikan skor corruption perceptions index (CPI). Terdapat beberapa negara yang mengalami peningkatan skor rule of law tetapi skor corruption perceptions index (CPI) menurun, atau sebaliknya. Terjadinya penurunan hasil skor rule of law tetapi skor corruption perceptions index (CPI) mengalami peningkatan terjadi pada beberapa negara antara lain: Malaysia, Filipina dan Vietnam (2012), Malaysia (2013), Thailand (2014), Indonesia, Myanmar dan Singapura (2015), Timor Leste (2016), Myanmar, Timor Leste dan Vietnam (2017), dan Filipina (2018). Sebaliknya, terjadinya peningkatan hasil skor rule of law tetapi skor corruption perceptions index (CPI) mengalami penurunan terjadi pada beberapa negara antara lain: Malaysia (2010), Singapura (2011), Singapura (2012), Thailand (2013), Singapura dan Timor Leste (2014), Singapura dan Thailand (2016), dan Timor Leste (2018). Berdasarkan hal tersebut, maka dapat disimpulkan bahwa tinggi rendahnya tingkat skor rule of law tidak memengaruhi peningkatan atau penurunan corruption perceptions index (CPI) di suatu negara.

\section{Pengaruh Control of Corruption Terhadap Tingkat Korupsi}

Hipotesis keenam menunjukkan bahwa control of corruption berpengaruh terhadap tingkat korupsi. Hasil pengujian hipotesis pada lampiran 13 nilai control of corruption $\left(\mathrm{X}_{6}\right)$ menunjukkan arah positif dengan nilai koefisien beta sebesar 0,113 dan nilai signifikansi sebesar 0,038 $<0,05$ sehingga dapat disimpulkan bahwa control of corruption memiliki pengaruh terhadap tingkat korupsi atau $\mathrm{H}_{6}$ terdukung.

Hasil penelitian ini mendukung penelitian yang dilakukan oleh Perdana dan Santosa (2012) yang menyatakan bahwa control of corruption memiliki pengaruh yang signifikan terhadap corruption perceptions index (indeks perspektif korupsi). Perdana dan Santosa (2012) juga menyatakan bahwa proses terbentuknya korupsi dipengaruhi oleh tingkat kontrol pemerintah dalam tindak pidana korupsi, hal ini 
dapat memicu terjadinya tindak korupsi dalam birokrasi suatu negara. Hasil penelitian ini mendukung survei yang dilakukan oleh Transparency International (2009) dalam Global Corruption Barometer yang menyajikan temuan-temuan pada negara dimana survei dilakukan terkait penilaian responden terhadap kemampuan pemerintah dalam pemberantasan korupsi. Hasil survei pada negara di wilayah Asia Tenggara menujukkan bahwa empat dari tujuh negara dalam survei yakni Brunei Darussalam, Kamboja, Indonesia, dan Singapura meyatakan bahwa pemerintah secara efektif telah melakukan pemberantasan korupsi. Sedangkan, tiga dari tujuh negara dalam survei yakni Malaysia, Filipina, dan Thailand menyatakan bahwa pemerintah tidak efektif dalam upaya pemberantasan korupsi (lihat lampiran 15). Maka dapat ditarik kesimpulan bahwa keefektifan pemerintah dalam pemberantasan korupsi dapat berpengaruh kepada tingkat korupsi di suatu negara.

Komitmen dalam pemberantasan korupsi secara internasional telah dimulai sejak terbentuknya konvensi anti-korupsi internasional pada tahun 2003 yaitu UNCAC (The United Nations Convention Against Corruption). Konvensi ini telah menjadi instrumen hukum internasional dalam mendukung pemberantasan korupsi, kejahatan terorganisir, kejahatan ekonomi dan pencucian uang. Dengan menandatangani dan mengesahkan status keanggotaan UNCAC pada akhir tahun 2003, hal ini menunjukkan keseriusan negara-negara anggota ASEAN dalam memerangi korupsi di negaranya. Perjanjian internasional antara negara-negara anggota ASEAN sejak tahun 2003 ini telah memprakasai terbentuknya SEA-PAC (South East Asia Parties Againts Corruption) pada tahun 2008 yaitu komunitas anti-korupsi di Asia Tenggara yang menyediakan instrumen internasional dalam pemberantasan korupsi yang tertuang dalam UNCAC.

Dalam meningkatkan upaya pemberantasan korupsi setiap negara anggota ASEAN masing-masing memiliki lembaga independen pemberantasan korupsi. Indonesia mempunyai Komisi Pemberantasan Korupsi (2002), Brunei Darussalam mempunyai Anti-Corruption Bureau (1982), Vietnam mempunyai Government Inspectorate of Vietnam (1945), Thailand mempunyai National Anti-Corruption Commission (1999), Singapura mempunyai Corrupt Practices Investigation Bureau (1952), Malaysia mempunyai Malaysian Anti-Corruption Commission (1967), Laos mempunyai State Inspection and Anti-Corruption Authority - Lao PDR (2001), Myanmar mempunyai Anti-Corruption Commission The Republic of the Union of Myanmar (2014), dan Filipina mempunyai Office of The Ombudsman (1987). Berdasarkan keseriusan masing-masing negara dengan memberikan wewenang eksklusif kepada lembaga-lembaga diatas dan membuktikan bahwa negara-negara anggota ASEAN memiliki komitmen kuat untuk melakukan pemberantasan korupsi di negaranya masing-masing (Amrullah dan Natamiharja, 2019).

\section{E. SIMPULAN DAN SARAN}

\section{Kesimpulan}

Penelitian ini bertujuan untuk melihat pengaruh elemen good governance terhadap tingkat korupsi di Asia Tenggara yang memiliki Corruption Perceptions Index yang dikeluarkan oleh Transparency International dan memiliki indikator good governance yang dikeluarkan oleh Worldwide Governance Indicators, World Bank tahun 2009-2018. Penelitian ini menggunakan analisis regresi berganda sebagai alat analisis hipotesis dengan menggunakan Program IBM SPSS Statistics versi 24. Berdasarkan hasil pengujian hipotesis, dari variabel independen maka dapat disimpulkan sebagai berikut; voice and accountability tidak berpengaruh terhadap tingkat korupsi di Asia Tenggara, political stability and absence 
of violencel terrorism tidak berpengaruh terhadap tingkat korupsi di Asia Tenggara, government effectiveness berpengaruh terhadap tingkat korupsi di Asia Tenggara, regulatory quality berpengaruh terhadap tingkat korupsi di Asia Tenggara, rule of law tidak berpengaruh terhadap tingkat korupsi di Asia Tenggara, control of corruption berpengaruh terhadap tingkat korupsi di Asia Tenggara.

\section{Implikasi}

Implikasi hasil penelitian ini yaitu dalam peningkatan good governance akan berdampak langsung terhadap penurunan tingkat korupsi. Namun, masih terdapat beberapa elemen good governance yang belum maksimal dalam penurunan tingkat korupsi di Asia Tenggara, seperti masih rendahnya tingkat partisipasi masyarakat dalam proses politik, rendahnya kebebasan bereskpresi, berserikat, keterbukaan, dan kebebasan pers. Selain itu, semakin rendah ketidakstabilan politik, diberhentikannya pemerintahan secara tidak konstitusional, serta kemungkinan terjadinya tindak kekerasan dan terorisme, serta semakin rendahnya kepercayaan pemerintah terhadap tegaknya aturan hukum masyarakat, kualitas penegakan hukum, aparatur sipil, kepolisian dan pengadilan serta kemungkinan terjadinya tindak kejahatan dan kekerasan. Hal ini menyebabkan belum maksimalnya pemberantasan korupsi yang terjadi di sektor publik, sehingga perlu dilakukan pembenahan dan penyusunan kebijakan mengenai upaya pemberantasan korupsi yang efektif dan efisien. Selain itu, penguatan lembaga independen terkait pemberantasan korupsi, peraturan perundangundangan, serta meningkatkan kesadaran hukum masyarakat terkait tindak pidana korupsi perlu dilakukan agar tingkat korupsi di Asia Tenggara akan berangsur-angsur menurun.

\section{Keterbatasan Penelitian}

Keterbatasan dalam penelitian ini adalah sampel dari penelitian yang digunakan hanya terbatas pada negara-negara di Asia Tenggara, indeks pengukuran variabel dependen yaitu tingkat korupsi yang digunakan dalam penelitian ini menggunakan corruption perceptions index yang dikeluarkan oleh Transparency International, sedangkan masih terdapat beberapa indeks pengukuran lain yang tidak digunakan dalam penelitian ini, dan indikator good governance yang digunakan memiliki hubungan linear antar variabel sehingga menyebabkan masalah multikolinearitas. Indikator pengukuran good governance yang dikeluarkan oleh Worldwide Governance Indicators (World Bank) masih menggunakan metode pengukuran yang sama setiap tahunnya dari tahun 1996 sampai dengan saat ini, sehingga tidak adanya pembaharuan metode pengukuran yang lebih akurat untuk digunakan. Saran yang diberikan peneliti bagi pihak pemerintah adalah diharapkan perlu dilakukan pembenahan dan penyusunan kebijakan mengenai upaya penurunan tingkat korupsi yang efektif dan efisien, dan diharapkan bagi pemerintah untuk melakukan penguatan lembaga independen terkait pemberantasan korupsi, peraturan perundang-undangan, serta meningkatkan kesadaran hukum masyarakat terkait tindak pidana korupsi perlu dilakukan agar tingkat korupsi di Asia Tenggara akan berangsur-angsur menurun. Saran yang diberikan peneliti bagi peneliti selanjutnya adalah diharapkan dapat menggunakan sampel yang lebih luas seperti negara-negara yang terdapat di suatu benua atau melakukan perbandingan antar benua sehingga dapat mengetahui perbedaan tingkat korupsi di suatu negara, dan diharapkan dapat menggunakan beberapa indeks pengukuran tingkat korupsi sebagai bahan pertimbangan dan perbandingan sehingga mendapatkan hasil pengujian yang lebih akurat dan dapat diandalkan. 


\section{REFERENSI}

Aidt, T. S. 2003. Review: Economic Analysis of Corruption: A Survey. Jurnal Ekonomi 113(491): F632F652.

Amrullah, Rinaldy dan Rudi Natamiharja. 2019. Asset Recovery in the Criminal Act of Corruption in ASEAN. http://repository.lppm.unila.ac.id/15949/. Diakses pada 16 Februari 2020.

Apriyanti, Devi. 2014. Reformasi Politik dan Ekonomi di Myanmar Pada Masa Pemerintahan Presiden U Thein Sein (2011-2013). Jurnal Online Mahasiswa Fakultas Ilmu Sosial dan Ilmu Politik. Vol. 1, No. 2.

Azra, Azyumardi. 2002. Korupsi dalam Perspektif Good Governance. Jurnal Kriminologi Indonesia. Vol. 2, No. 1. 31-36.

Clark, April K. 2017. Measuring Corruption: Transparency International's "Corruption Perception Index”. Corruption, Accountability and Discretion. Public Policy and Governance. 3-22.

Dana, Badara Shofi, Eni Supriyanti, dan Irin Cahyawati. 2017. Pertumbuhan Ekonomi dan Korupsi di Indonesia: Pendekatan Good Governance. SNAPER-EBIS. Hal. 244-248. ISBN : 978-602-5617-01-0.

Danang, S. 2013. Metodologi Penelitian Akuntansi. Bandung. PT Refika Aditama Anggota Ikapi.

Edo, NK Johanes, Raymundus Rikang RW dan Cornel Dimas SK. 2012. Literasi Kaum Muda tentang Good Governance Melalui Isu Korupsi di Televisi. Jurnal Ilmu Komunikasi. Vol. 9, No. 1. 56-59.

Eisenhardt, KM. 1989. Agency Theory: An Assessment and Review. The Academy of Management Review. Vol. 14, No. 1, 57-74.

Elwina, Marcella S. 2011. Pendidikan Anti Korupsi untuk Perguruan Tinggi. Jakarta: Kemendikbud. ISBN: 978-602-9290-15-8.

Fatkhuri. 2017. Korupsi Dalam Birokrasi dan Strategi Pencegahannya. Jurnal Ilmiah Manajemen Publik dan Kebijakan Sosial. Vol. 1, No. 2.

Gerring, John. dan Strom C Thacker. 2005. Do Neoliberal Policies Deter Political Corruption?. International Organization. Vol. 59. pp 233-254.

Ghozali, Imam. 2016. Aplikasi Analisis Multivariate dengan Program IBM SPSS 21 Update PLS Regresi. Semarang: Badan Penerbit Universitas Dipenogoro.

Indonesia Corruption Watch. 2018. Tren Vonis Kasus Korupsi 2018. https://antikorupsi.org/id/tren/trenvonis-kasus-korupsi-2018. Diakses pada 01 Maret 2020.

Jahja, Juni Syafrien. 2012. Say No to Korupsi. Jakarta: Visimedia. Hal. 7-8.

Jain, Arvind K. 2001. Corruption: A Review. Journal of Economic Surveys. Vol. 15, No.1.

Javaid, Umbreen. 2010. Corruption and Its Deep Impact on Good Governance in Pakistan. Pakistan Economic and Social Review. Vol. 48, No. 1. pp. 123-134.

Jensen, Michael C dan William H Meckling. 1976. Theory of the Firm: Managerial Behavior, Agency Costs and Ownership Structure. Journal of Financial Economics (JFE). Vol. 3, No.4.

Karsona, Agus Mulya. 2011. Pendidikan Anti Korupsi untuk Perguruan Tinggi. Jakarta: Kemendikbud. ISBN: 978-602-9290-15-8.

Kaufmann, Daniel, Aart Kraay dan Massimo Mastruzzi. 2010. The Worldwide Governance Indicators: Methodology and Analytical Issues. World Bank Policy Research Working Paper. No. 5430.

Kharisma, Bayu. 2014. Good Governance Sebagai Suatu Konsep dan Mengapa Penting dalam Sektor Publik dan Swasta: Suatu Pendekatan Ekonomi Kelembagaan. Jurnal Buletin Studi Ekonomi. Vol. 19, No. 1.

Kolstad, I dan A Wiig. 2008. Is Transparency the Key to Reducing Corruption in Resource-Rich Countries?.World Development.

Kurniadi, Yusuf. 2011. Pendidikan Anti Korupsi untuk Perguruan Tinggi. Jakarta: Kemendikbud. ISBN: 978-602-9290-15-8.

Lambsdorff, Johan Graf. 2007. The Institutional Economics of Corruption and Reform: Theory, Evidence, and Policy. Cambridge University Press. JF1525.C66L36 2007.

Lewis, Maureen. 2006. Governance and Corruption in Public Health Care Systems. Center for Global Development. No. 78.

Perdana, Putra dan Purbayu Budi Santosa. 2012. Efektivitas Lembaga Birokrasi dan Tingkat Korupsi Terhadap Investasi pada Enam Negara Asean (Filipina, Indonesia, Malaysia, Myanmar, Singapura, dan Thailand) Tahun 2004-2010. Diponegoro Journal of Economics. Vol. 1, No. 1. 
Political \& Economic Risk Consultancy, Ltd. 2018. Annual Review of Corruption in Asia - 2018. Independent Fortnightly Report on Asian Business and Politics. March. No. 992.

Pradiptyo, Rimawan. 2016. Modul Integritas Bisnis: Dampak Sosial Korupsi. Jakarta: Direktorat Pendidikan dan Pelayanan Masyarakat Kedeputian Bidang Pencegahan.

Prakoso, Septyanto Galan. 2014. The Path of Military Power Interference in the Politics of Thailand. Indonesian Journal of International Studies. Vol 1, No. 1.

Rasul, Sjahruddin. 2009. Penerapan Good Governance di Indonesia Dalam Upaya Pencegahan Tindak Pidana Korupsi. Mimbar Hukum. Vol. 21, No. 3. Hal. 409-628.

Reporters Without Borders. 2011. World Press Freedom Index 2011/2012. https://rsf.org/en/world-pressfreedom-index-20112012. Diakses pada 19 Februari 2020.

Republik Indonesia. 2001. Undang-Undang No. 20 Tahun 2001 tentang Pemberantasan Tindak Pidana Korupsi. Lembaran Negara RI Tahun 2001, No. 134. Sekretariat Negara. Jakarta.

Spiteri, Jonathan. dan Marie Briguglio. 2018. Does Good Governance Foster Trust in Government? An Empirical Analysis. Contemporary Studies in Economic and Financial Analysis. Vol. 99. 121-137.

Svensson, Jakob. 2005. Eight Questions about Corruption. Journal of Economic Perspectives. Vol. 19, No. 3.

Transparency International. 2009. Global Corruption Barometer. ISBN: 978-3-935711-28-9. 2010. Global Corruption Barometer.

https://www.transparency.org/gcb201011/in_detail. Diakses pada 25 Januari 2020.

Treisman, Daniel. 2000. The Causes of Corruption: A Cross-National Study. Journal of Public

Economics. Vol. 76, No. 3. pp 399-457.

Tuanakotta, Theodorus M. 2012. Akuntansi Forensik dan Audit Investigatif. Jakarta: Salemba Empat.

Umar, Haryono. 2011. Menghitung Kembali Dampak Korupsi. Jurnal Bisnis dan Manajemen. Vol. 7, No. 1. ISSN 1412-3681.

Wibowo. Satrio Budi. 2011. Indeks Persepsi Korupsi Ditinjau dari IQ Nasional dan GDP di Asia Tenggara. GUIDENA. Vol. 1, No. 1.

Wiliyanti, Rizke, Ria Nelly Sari dan Edfan Darlis. 2014. Pengaruh Tata Kelola Pemerintahan, Efektivitas Pengendalian Internal, dan Peran Auditor Internal Terhadap Tingkat Kecurangan. Jurnal Ekonomi.

Vol. 1, No. 1.

World Bank. 1992. Governance and Development. Washington DC: World Bank. 2007. A Decade of Measuring The Quality of Governance. Washington DC: World Bank. 